\title{
RESENHA
}

\section{ESSENCE OF DECISION: EXPLAINING THE CUBAN MISSILE CRISIS}

Allison, G. T., \& Zelikow, P. (1999). Essence of decision: Explaining the Cuban missile crisis (Vol. 2). New York: \begin{abstract}
Longman. (n) $\sqrt{2}$
\end{abstract}

\author{
Christian Falaster \\ Universidade Nove de Julho - UNINOVE. \\ Av. Francisco Matarazzo n. 612 - Bloco C $2^{\circ}$ Andar. \\ E-mail: christianfalaster@gmail.com
}

A primeira versão do livro, escrito por Allison em 1979 trouxe uma análise detalhada das decisões americanas e soviéticas por meio de um modelo RAM (Rational Actor Model). O modelo do ator racional observa as decisões por meios lógicos e foi amplamente aceito pelas escolas de relações internacionais e políticas. Porém, com a revelação de documentos antes secretos e das "Fitas secretas da Casa Branca", com áudios detalhados, o livro foi reeditado com mais dois modelos de análise.

O livro inicia com a explicação do modelo clássico do ator racional. Posteriormente, faz um primeiro corte sobre o evento, com uma análise detalhada de hipóteses sobre as intenções soviéticas em posicionar misseis em Cuba, as possíveis soluções avaliadas pelos americanos, sua decisão, e os motivos que levaram Krushschev a concordar com Kennedy. Os autores então apresentam o modelo do comportamento organizacional. O modelo organizacional oferece uma segunda lente sobre o evento, onde é possível compreender como as capacidades e os modos de agir das organizações envolvidas (a CIA, o exército americano, o exército soviético, e o governo cubano) levaram à descoberta dos misseis, às possíveis opções 
americanas e às decisões finais. O terceiro modelo dos autores (Modelo de Políticas Governamentais) busca explicar o evento com uma lente focada em instituições, relações de poder e posições de barganha. Com os três modelos, é possível compreender a crise e seus protagonistas com considerável precisão.

Os três modelos oferecem contribuições ímpares para os estudos de tomada de decisão em estratégia. Seu uso pode ser implementado em diferentes situações, inclusive tomando corporações como foco de análise (principalmente pelo modelo do comportamento organizacional). O Modelo do Ator Racional pode explicar o comportamento das empresas e seus decisores por meio de análises de custos e benefícios, encadeamentos de decisões, objetivos e consequências. Já o modelo do Comportamento Organizacional pode explicar as relações com outras organizações, além de oferecer um foco sobre as capacidades, cultura e padrões comportamentais das organizações. O modelo de Políticas Governamentais é - apesar de seu nome - especialmente importante quando tratadas as estratégias de negócios internacionais para as empresas. Este terceiro modelo traz à discussão o poder das instituições na tomada de decisão, além de possibilitar a análise das empresas e seus decisores por uma lente que evidencia o poder de barganha e as relações de agência.

A obra de Allison e Zelikow (1999) traz importantes lições para acadêmicos e executivos nas análises de tomada de decisão. Os modelos propostos pelos autores são amplamente utilizados por acadêmicos e analistas de relações internacionais e de ciências políticas, porém seu uso em estratégia ainda é relativamente pequeno. A utilização destes modelos oferece uma imensa agenda de pesquisa que pode ser explorada por acadêmicos que estudam utilizando teorias de tomada de decisão, estratégia como prática, teoria da agência e a teoria institucional. O livro traz também contribuições para o público executivo, oferecendo diferentes lentes para as perspectivas na decisão e na análise de decisões. 